\title{
Nutritional status of drug addicts undergoing detoxification: prevalence of malnutrition and influence of illicit drugs and lifestyle
}

\author{
S. K. Nazrul Islam ${ }^{1}$, Kazi Jahangir Hossain ${ }^{1}$, Afsaruddin Ahmed and Monira Ahsan ${ }^{2}$ \\ ${ }^{1}$ Institute of Nutrition and Food Science and ${ }^{2}$ Department of Pharmacy, University of Dhaka, Dhaka-1000, Bangladesh
}

(Received 8 December 2000 - Revised 19 April 2002 - Accepted 7 July 2002)

\begin{abstract}
The aim of the present study was to investigate the nutritional status of drug addicts, the prevalence of malnutrition among them and the influence of their drug habit and lifestyle factors on their nutritional indices. The study was conducted among 253 male drug addicts, who sought detoxification at the Central Drug Addiction Treatment Hospital, Dhaka, during the period of June 1998-July 1999. One hundred age-, height- and socioeconomic-matched non-addicted healthy men were recruited by convenience as cohort controls. Results showed that the drug addicts had significantly $(P<0.001)$ lowered BMI, haemoglobin, and serum total protein and albumin levels. Clinical signs of nutrient deficiency were diagnosed in about $74 \%$ of drug addicts. The BMI, biochemical values and nutrient deficiency signs indicated that more than $60 \%$ of drug addicts were suffering from multiple malnutrition. One-way ANOVA demonstrated a significant $(P<0.05)$ negative correlation between drug habit, sexually transmitted diseases and selected nutritional indices, and a positive correlation between education, income and the nutritional indices. A series of multiple regression analyses revealed that education, income and age showed significantly predicted BMI and biochemical indices, and the group (non-drug addicts or drug addicts) had a significant negative effect on these parameters in favour of controls.
\end{abstract}

Drug addiction: Nutritional status: Drug habit: Lifestyle

Drug addiction is a lifestyle disease. In recent times it has become a universal social and public health problem. No nation is immune to the horrendous consequences of illicit drug use. Devastation of family and social values has reached unprecedented levels. It has become a challenge to traditional and civic human norms and values (Finnegan, 1998). Emergence of illicit drug use has resulted in an explosive social violence around the world. Productive young adults are wading into the sea of drug experimentation (Johnson \& Gerstein, 1998).

Drug addiction induces immunonutritional deficiency (Varela et al. 1997a,b). Use of illicit drugs produces multiple nutrient deficiencies or malnutrition (Varela et al. 1997a; Islam et al. 2001), which is the most common cause of immunodeficiency (Beisel, 1996; Chandra, 1997, 2001; Hegde et al. 1999). Immunocompetence is a sensitive and functional determinant of nutritional status because it is altered even before the onset of clinical symptoms of malnutrition (Varela et al. 1997b). Illicit drugs are themselves immunosuppressive (Brown et al. 1974; Rouveix, 1992; Courssons-Reed et al. 1994; Carr
\& Serou, 1995; Thomas et al. 1995; Miyagi et al. 2000). Use of these drugs undermines appetite (Vasko, 1992), affects food habits (Mohs et al. 1990), leading drug addicts to crave 'empty-energy', potentially nutrient-deficient foods (Morabia et al. 1989), and causes micronutrient deficiency (Islam et al. 2001). Thus, the use of illicit drugs produces immunonutritional deficiencies, and influences susceptibility to infectious agents, including HIV infection (Varela et al. 1997a,b). In addition drug addicts' behavioural risk factors such as needle-sharing, unprotected sex, sex with multiple partners, etc. (Bluthenthal et al. 2000; Booth et al. 2000; Islam et al. 2000) ranks them at the highest risk of HIV infection (Varela et al. 1997a; Choi et al. 2000).

Because of its geographical position in the middle of the world's two largest illicit drug-producing regions, the 'Golden Triangle' and the 'Golden Crescent' (United Nations International Drug Control Programme, 1997), Bangladesh is being used as a trans-shipment point for the international drug markets. This has resulted in severe infliction of drug addiction in Bangladesh, which 
is rising with time. As in the developed world (Johnson \& Gerstein, 1998), illicit drug use amongst young adults is also soaring (Islam et al. 2000). It has also been addressed as a social and health problem. However, despite a focus on its fatal consequences worldwide (Califano, 1998), until recently research on illicit drug use has received little attention in Bangladesh. In continuation of our previous attempts (Islam et al. 2000, 2001), we report here the nutritional status of drug addicts and influence of their drug habit and lifestyle factors on their nutritional indices.

\section{Subjects and methods \\ Study population}

The study was conducted among 253 male drug addicts of age 18-45 years during the period of June 1998-July 1999. They were multi-drug users, principally using heroin, cannabis, phensedyl (codeine, ephedrine and promethazine), Tidigesic (buprenorphine) and pethedine injections, and sought detoxification therapy at the Central Drug Addiction Treatment Hospital, Tejgaon, Dhaka (the only government hospital in Bangladesh that provides detoxification facilities solely for male drug addicts). Exclusion criteria included medical disorders precluding a current acute or chronic illness, impaired hepatic or renal function, cardiac disorders, tuberculosis, cancers, severe asthma, using prescribed medicines and alcoholism. In addition, re-admissions within 1 year and period of addiction less than 1 year were also excluded. One hundred age-, height and socioeconomic-(education, occupation, income, marital status) matched non-addicted healthy men were recruited by convenience as cohort controls; they did not use any wetted or dried or smokeless raw or flavoured tobacco, betel leaves or nuts, or cigarettes. The controls were purposely selected so that the drug addicts and non-addicted controls were equivalent in group percentage of age, height and socioeconomic parameters.
Research instruments were anthropometric data, an interviewer-administered questionnaire and blood specimens.

The questionnaire was developed and pre-tested among hospitalized drug addicts, who were then excluded from the study population. It was designed to include: anthropometric data such as height and weight; socioeconomic information such as education, occupation, income, age, marital status; clinical signs of nutrient deficiencies such as angular stomatitis, stomatitis, spongy or bleeding gums, steatorrhoea; drug habit such as number of illicit drugs and period of addiction; sexually transmitted diseases such as syphilis and gonorrhoea. After briefing the subjects on the perspective of the present study and having written consent, information was recorded in the questionnaire and blood specimens were collected from each of the study subjects. Privacy of the patients was maintained. Ethical permission was taken from the Director of the Central Drug Addiction Treatment Hospital.

Anthropometric data and socioeconomic information of each of the subjects were recorded at the time of admission into the hospital. Their body weight and height (without wearing shoes) were measured under the direct supervision of a physician using a measuring scale (Physician adult metric scale; Detecto Scale Inc, Brooklyn, New York, USA). The physician also diagnosed clinical signs of nutrient deficiency during hospitalization.

\section{Blood analysis}

A venous blood sample $(5 \mathrm{ml})$ was collected from the antecubital vein of each of the drug addicts and nonaddicted controls. A whole blood sample $(20 \mathrm{ml})$ was used to estimate haemoglobin by the cyanmethhaemoglobin method using Boeringer Mannheim (Mannheim, Germany) kits. Serum was then extracted and stored at $-20^{\circ} \mathrm{C}$. Serum total protein and albumin were estimated by the biuret and bromocresol-green methods respectively by using Boeringer Mannheim kits. Precenorm U (Boeringer Mannheim) was used as standard quality sera. Absor-

Table 1. Height, weight, BMI and chronic energy deficiency (CED) of drug addicts and non-addicted controls

(Mean values with their standard deviations)

\begin{tabular}{|c|c|c|c|c|c|c|c|c|c|c|}
\hline \multirow[b]{2}{*}{ Parameter } & \multicolumn{4}{|c|}{ Drug addicts ( $n$ 253) } & \multicolumn{4}{|c|}{ Non-addicted controls ( $n$ 100) } & \multirow[b]{2}{*}{$t$} & \multirow[b]{2}{*}{$P$} \\
\hline & $n$ & $\%$ & Mean & SD & $n$ & $\%$ & Mean & SD & & \\
\hline \multicolumn{11}{|l|}{ Height (m) } \\
\hline $1.50-1.60$ & 67 & $26 \cdot 4$ & & & 26 & $26 \cdot 0$ & & & & \\
\hline $1.61-1.70$ & 154 & $60 \cdot 9$ & 164.5 & $5 \cdot 7$ & 61 & $61 \cdot 0$ & 164.4 & $6 \cdot 0$ & 0.165 & $>0.05$ \\
\hline $1.71-1.80$ & 32 & $12 \cdot 7$ & & & 13 & $13 \cdot 0$ & & & & \\
\hline \multicolumn{11}{|l|}{ Weight (kg) } \\
\hline $40-50$ & & $67 \cdot 1$ & & & 29 & $29 \cdot 0$ & & & & \\
\hline $51-60$ & & 24.5 & $49 \cdot 8$ & $7 \cdot 2$ & 45 & $45 \cdot 0$ & $57 \cdot 2$ & $7 \cdot 7$ & 8.51 & $<0.003$ \\
\hline $61-75$ & & 8.4 & & & 26 & $26 \cdot 0$ & & & & \\
\hline \multicolumn{11}{|l|}{$\mathrm{BMI}\left(\mathrm{kg} / \mathrm{m}^{2}\right)$} \\
\hline <16.0 (CED-III) & 37 & $14 \cdot 6$ & & & 2 & $2 \cdot 0$ & & & & \\
\hline $16 \cdot 0-16 \cdot 9$ (CED-II) & 46 & $18 \cdot 2$ & $18 \cdot 3$ & 2.47 & 3 & 3.0 & $21 \cdot 1$ & $2 \cdot 8$ & 9.48 & $<0.001$ \\
\hline $17 \cdot 0-18.4$ (CED-I) & 69 & $27 \cdot 3$ & & & 10 & $10 \cdot 0$ & & & & \\
\hline $18.5-25.0$ (normal) $^{*}$ & 93 & $36 \cdot 7$ & & & 74 & $74 \cdot 0$ & & & & \\
\hline$>25.0$ (Obese) & 8 & $3 \cdot 2$ & & & 11 & $11 \cdot 0$ & & & & \\
\hline
\end{tabular}

\footnotetext{
*Normal human BMI ranges 18.5-25 (Food and Agriculture Organization, 1994).
} 
bance was measured in a spectrophotometer (UV-1201, UV-VIS, Spectrophotometer; Shimadzu Corporation, Kyoto, Japan).

\section{Statistical analysis}

SPSS software package (version 9.0; SPSS Inc., Chicago, IL, USA) was used to analyse the data. Descriptive statistics was used for all variables. Values are expressed as percentage, mean and standard deviation. Comparison of anthropometric and biochemical data of the drug addicts with those of the cohort controls was performed by cross-table variables and independent sample $t$ test. Oneway ANOVA was used to assess the influence of drug habit, sexually transmitted diseases and socioeconomic factors on their nutritional indices. Bivariate correlations and multiple linear regression analyses were performed to determine the extent of contribution of socioeconomic factors to affect BMI and biochemical parameters.

\section{Results}

Anthropometric data of the study population are described in Table 1. Drug addicts had significantly reduced mean BMI $(P<0.001)$ values compared with those of the nonaddicted controls. More than $60 \%$ ( $n$ 152) drug addicts were suffering from varying degrees of chronic energy deficiency (CED), of which $14.6 \%$ ( $n$ 37), $18.2 \%$ ( $n$ 46) and $27.3 \%(n$ 69) addicts were in CED-III, CED-II and CED-I grades respectively (Food and Agriculture Organization, 1994).

On selected biochemical indices drug addicts were found to have lower levels than the controls (Table 2). Haemoglobin and total protein values indicated that over $60 \%$ drug addicts had anaemia (Food and Agriculture Organization, 1995; Latham, 1997) and protein deficiency
(Ganong, 1997; Rand \& Murray, 2000). Clinical signs of nutrient deficiency (Mason \& Swash, 1980; Ogilvie \& Evans, 1987) were diagnosed in about $74 \%$ ( $n$ 187) drug addicts (Table 3 ); of them, 31.1\% ( $n$ 79) had multiple deficiency signs and $42.8 \%$ ( $n$ 108) had single deficiency signs. Thus, the BMI, biochemical parameters and clinical signs of nutrient deficiency findings indicated that more than $60 \%$ drug addicts were found to be suffering from a severe to mild degree of multiple malnutrition.

Table 4 shows the influence of drug habit and sexually transmitted diseases on the nutritional indices of drug addicts. It was observed that multiple drug use had a significant negative effect only on BMI $(P=0.03)$, but longer periods of addiction had resulted in a significant $(P=0.00-0.02)$ reduction in BMI, haemoglobin, total protein and albumin values. Addicts with sexually transmitted diseases were found to have significantly $(P=0 \cdot 00-0.02)$ lowered haemoglobin, total protein and albumin levels.

Socioeconomic factors of the studied drug addicts and their controls had influence on their BMI and biochemical parameters (Table 5). In drug addicts, there was a significant $(P<0.02)$ positive correlation between education and nutritional indices (BMI, haemoglobin, total protein and albumin). Income also similarly affected BMI, haemoglobin and total protein. For the non-addicted controls, education had a negative effect on haemoglobin $(P=0.003)$ and age had a positive effect on albumin $(P=0.019)$. Analysis by profession showed that the nonaddicted businessmen were found to have higher haemoglobin $(P=0.037)$, protein $(P=0.001)$ and lowered albumin $(P=0.029)$. BMI of the controls was found to be positively influenced by age $(P=0.035)$ and marital status $(P=0 \cdot 019)$.

There were significant differences in BMI and biochemical parameters between drug addicts and nonaddicted controls (Tables 1 and 2). BMI and biochemical

Table 2. Haemoglobin, total serum protein and albumin levels of drug addicts and non-addicted controls* (Mean values with their standard deviations)

\begin{tabular}{|c|c|c|c|c|c|c|c|c|c|c|}
\hline \multirow[b]{2}{*}{ Biochemical parameter } & \multicolumn{4}{|c|}{ Drug addicts ( $n$ 253) } & \multicolumn{4}{|c|}{ Non-addicted controls ( $n$ 100) } & \multirow[b]{2}{*}{$t$} & \multirow[b]{2}{*}{$P$} \\
\hline & $n$ & $\%$ & Mean & SD & $n$ & $\%$ & Mean & SD & & \\
\hline \multicolumn{11}{|l|}{ Haemoglobin $(g / l) \dagger$} \\
\hline$<70.0$ & 15 & $5 \cdot 9$ & & & 0 & & & & & \\
\hline $70 \cdot 0-99.9$ & 28 & $11 \cdot 1$ & & & 2 & $2 \cdot 0$ & & & & \\
\hline $100 \cdot 0-129 \cdot 9$ & 111 & $43 \cdot 8$ & $118 \cdot 0$ & $26 \cdot 3$ & 19 & $19 \cdot 0$ & $141 \cdot 0$ & $15 \cdot 0$ & $10 \cdot 13$ & $<0.001$ \\
\hline $130 \cdot 0-160 \cdot 0$ & 94 & $37 \cdot 2$ & & & 68 & $68 \cdot 0$ & & & & \\
\hline$>160 \cdot 0$ & 5 & $2 \cdot 0$ & & & 11 & $11 \cdot 0$ & & & & \\
\hline \multicolumn{11}{|l|}{ Total protein $(\mathrm{g} / \mathrm{l}) \ddagger$} \\
\hline$<46.0$ & 19 & $7 \cdot 5$ & & & 0 & & & & & \\
\hline $46 \cdot 0-65 \cdot 9$ & 131 & $51 \cdot 8$ & 62.9 & $11 \cdot 8$ & 17 & $17 \cdot 0$ & $73 \cdot 6$ & $8 \cdot 8$ & 9.52 & $<0.001$ \\
\hline $66 \cdot 0-85 \cdot 0$ & 96 & $37 \cdot 9$ & & & 75 & $75 \cdot 0$ & & & & \\
\hline$>85.0$ & 7 & $2 \cdot 8$ & & & 8 & $8 \cdot 0$ & & & & \\
\hline \multicolumn{11}{|l|}{ Albumin $(g / l) \S$} \\
\hline$<20.0$ & 3 & $1 \cdot 2$ & & & 0 & & & & & \\
\hline $20 \cdot 0-34.9$ & 93 & $36 \cdot 7$ & $37 \cdot 2$ & 6.9 & 9 & $9 \cdot 0$ & $42 \cdot 6$ & 6.9 & 6.57 & $<0.001$ \\
\hline $35 \cdot 0-50 \cdot 0$ & 151 & $59 \cdot 7$ & & & 77 & $77 \cdot 0$ & & & & \\
\hline$>50 \cdot 0$ & 6 & 2.4 & & & 14 & $14 \cdot 0$ & & & & \\
\hline
\end{tabular}

* For details of subjects and procedures, see Table 1 and p. 508

† Normal human haemoglobin ranges 130.0-160.0 g/l (Food and Agriculture Organization, 1995; Latham, 1997).

$\ddagger$ Total serum protein ranges $70.0-75.0 \mathrm{~g} / \mathrm{l}$ (Rand \& Murray, 2000).

$\S$ Albumin ranges 35-50 g/l (Ganong, 1997). 
Table 3. Clinical signs of nutrient deficiencies in drug addicts ( $n$ 253)

\begin{tabular}{lcc}
\hline Clinical sign & Number & Percentage \\
\hline Sign of deficiency & & \\
Angular stomatitis & 64 & $25 \cdot 3$ \\
Spongy or bleeding gums & 26 & $10 \cdot 3$ \\
Stomatitis & 11 & $4 \cdot 4$ \\
Steatorrhoea & 7 & $2 \cdot 8$ \\
Multiple signs & 79 & $31 \cdot 1$ \\
No sign of deficiency & 66 & $26 \cdot 1$ \\
\hline
\end{tabular}

parameters were affected by some socioeconomic factors for both drug addicts and non-addicted controls (Table 5). Therefore, to determine how much, in addition to illicit drug use, these socioeconomic factors contributed to affect BMI and biochemical parameters, a multiple linear regression model was used taking BMI and biochemical parameters as dependent variables. Before that, bivariate correlations were performed to find the relationship between dependent variables and the independent socioeconomic factors of drug addicts and non-addicted controls. Significant correlations were observed between: BMI, education and income; haemoglobin, total proteins and income; albumin, education and age. Therefore, by controlling the socioeconomic factors that influenced BMI and biochemical parameters, a series of linear regression analyses was performed. In the first analysis, education and income significantly predicted BMI. After controlling for these two factors, group (non-drug addicts or drug addicts) had a significant negative effect on BMI. Similarly when haemoglobin, total protein and albumin were used as dependent variables, group had an independent effect on each of them, even after controlling other socioeconomic variables in favour of controls (Table 6).

\section{Discussion}

Of the studied drug addicts, the majority (60-74\%) had below-normal BMI and biochemical values, and had clinical signs of nutrient deficiency. Lowered BMI and nutrient deficiencies have also been previously reported for drug addicts (Varela et al. 1997a,b; Himmelgreen et al. 1998; Islam et al. 2001). The reduced nutritional indices may be possibly because of the consumption of poorquality nutrient-deficient foods (Mohs et al. 1990; Vasko, 1992; Himmelgreen et al. 1998). The clinical signs of nutrient deficiency, particularly, are reported to be associated with micronutrient deficiencies (Leklem, 1996; Levine et al. 1996; Shearman, 1996; Nagati, 2001), which have also been documented for drug addicts (Varela et al. 1997a; Islam et al. 2001). The decreased BMI, haemoglobin and protein values in the drug addicts respectively indicate the presence of CED (Food and Agriculture Organization, 1995), anaemia (Food and Agriculture Organization, 1995; Latham, 1997) and proteinenergy malnutrition (Ganong, 1997; Rand \& Murray, 2000). Deficiency of antioxidant vitamins in this population of drug addicts has recently been reported (Islam et al. 2001). These findings demonstrate that drug addicts are suffering from multiple malnutrition, which is consistent to some extent with the previous reports of Varela et al. $(1997 a, b)$ for drug addicts. Thus, the prevalent multiple malnutrition developed by immunosuppressive illicit drugs produces immunodeficiency or down regulates immunocompetence (Chandra, 1997, 2001).

Analysis of their drug habit showed that use of multiple drugs had a significant inverse correlation with BMI, but period of addiction affected all the nutritional parameters. Since it has been documented that the use of illicit drugs produces nutritional deficiencies (Chlebowski et al. 1993; Varela et al. 1997a,b) the use of multiple drugs for longer periods could result in greater deficiencies in nutrients and reduction in BMI. It was recorded that the majority of drug addicts (about $60 \%$ ) had sexually transmitted diseases and were suffering from multiple nutrient deficiencies. This outcome is consistent with the fact of synergy between malnutrition and infection (Scrimshaw

Table 4. Effect of drug habit and sexually transmitted diseases (STD) on BMI and biochemical parameters of drug addicts $(n 253) \dagger$

(Mean values with their standard deviations)

\begin{tabular}{|c|c|c|c|c|c|c|c|c|c|}
\hline \multirow[b]{2}{*}{ Parameter ... } & \multirow[b]{2}{*}{$\% n$} & \multicolumn{2}{|c|}{ BMI $\left(k g / m^{2}\right)$} & \multicolumn{2}{|c|}{$\begin{array}{l}\text { Haemoglobin } \\
(\mathrm{g} / \mathrm{l})\end{array}$} & \multicolumn{2}{|c|}{$\begin{array}{l}\text { Total protein } \\
(\mathrm{g} / \mathrm{l})\end{array}$} & \multicolumn{2}{|c|}{ Albumin (g/l) } \\
\hline & & Mean & $\mathrm{SD}$ & Mean & SD & Mean & $\mathrm{SD}$ & Mean & SD \\
\hline \multicolumn{10}{|l|}{ Number of drugs } \\
\hline $1-2$ & 39.5101 & $17 \cdot 8^{\star}$ & $2 \cdot 6$ & $119 \cdot 0$ & $29 \cdot 3$ & $62 \cdot 0$ & $10 \cdot 2$ & 37.5 & $7 \cdot 0$ \\
\hline 3 & 37.996 & $18 \cdot 3^{\star}$ & $2 \cdot 1$ & $115 \cdot 0$ & $27 \cdot 2$ & 63.9 & 11.4 & $36 \cdot 6$ & $7 \cdot 0$ \\
\hline 4 and $>4$ & 22.656 & $17 \cdot 3^{\star}$ & 1.6 & $124 \cdot 0$ & $16 \cdot 8$ & $62 \cdot 2$ & 14.4 & 37.8 & $7 \cdot 0$ \\
\hline \multicolumn{10}{|l|}{ Period of addiction (years) } \\
\hline$<5$ & 38.798 & $18 \cdot 3^{*}$ & $2 \cdot 6$ & $124 \cdot 0^{\star}$ & $20 \cdot 2$ & $64 \cdot 5^{\star}$ & $10 \cdot 4$ & $38 \cdot 2^{*}$ & $7 \cdot 0$ \\
\hline $5-10$ & $42 \cdot 7108$ & $17 \cdot 7^{\star}$ & $2 \cdot 2$ & $118 \cdot 0^{\star}$ & $26 \cdot 5$ & $64 \cdot 1^{\star}$ & $12 \cdot 3$ & $37.5^{\star}$ & $7 \cdot 0$ \\
\hline$>10$ & 18.647 & $17 \cdot 4^{*}$ & 1.3 & $105 \cdot 0^{*}$ & 32.5 & $55 \cdot 9^{\star}$ & $10 \cdot 4$ & $34 \cdot 6^{*}$ & $7 \cdot 0$ \\
\hline \multicolumn{10}{|l|}{ STD } \\
\hline Syphilis or gonorrhoea & $59 \cdot 3150$ & $17 \cdot 7$ & $2 \cdot 1$ & $115 \cdot 0^{*}$ & $24 \cdot 0$ & $61 \cdot 2^{\star}$ & 11.4 & $36 \cdot 1^{*}$ & $6 \cdot 0$ \\
\hline No STD & $40 \cdot 7103$ & $18 \cdot 1$ & $2 \cdot 4$ & $123 \cdot 0^{\star}$ & $28 \cdot 7$ & $65 \cdot 0^{\star}$ & $11 \cdot 8$ & $38.9^{*}$ & $7 \cdot 0$ \\
\hline
\end{tabular}

* Mean values within a column for number of drugs, period of addiction or STD were significantly different by one-way ANOVA $(P<0.05)$.

†For details of subjects and procedures, see Table 1 and p. 508. 
Table 5. Effect of socioeconomic factors on BMI and biochemical parameters of drug addicts and nonaddicted controlst

(Mean values with their standard deviations)

\begin{tabular}{|c|c|c|c|c|c|c|c|c|c|}
\hline \multirow[b]{2}{*}{ Parameter ... } & \multirow[b]{2}{*}{$\%(n)$} & \multicolumn{2}{|c|}{ BMI $\left(k g / m^{2}\right)$} & \multicolumn{2}{|c|}{$\begin{array}{l}\text { Haemoglobin } \\
(\mathrm{g} / \mathrm{l})\end{array}$} & \multicolumn{2}{|c|}{$\begin{array}{l}\text { Total protein } \\
(\mathrm{g} / \mathrm{l})\end{array}$} & \multicolumn{2}{|c|}{ Albumin $(\mathrm{g} / \mathrm{l})$} \\
\hline & & Mean & SD & Mean & SD & Mean & SD & Mean & SD \\
\hline \multicolumn{10}{|c|}{ Drug addicts ( $n$ 253) } \\
\hline \multicolumn{10}{|c|}{ Education (years) } \\
\hline $0-10$ & 61.3155 & $17 \cdot 4^{\star}$ & 1.9 & $115 \cdot 0^{*}$ & $28 \cdot 4$ & $61 \cdot 5^{\star}$ & $12 \cdot 2$ & $36 \cdot 3^{*}$ & $7 \cdot 1$ \\
\hline$>10$ & 38.798 & $18 \cdot 7^{*}$ & $2 \cdot 6$ & $123 \cdot 3^{*}$ & 21.7 & $65 \cdot 1^{*}$ & $10 \cdot 9$ & $38.8^{*}$ & $6 \cdot 2$ \\
\hline \multicolumn{10}{|l|}{ Occupation } \\
\hline Business & 45.5115 & $18 \cdot 0$ & $2 \cdot 3$ & $121 \cdot 1$ & $26 \cdot 5$ & 63.3 & $12 \cdot 9$ & $37 \cdot 2$ & $7 \cdot 1$ \\
\hline Others & 54.5138 & $17 \cdot 9$ & $2 \cdot 3$ & $115 \cdot 8$ & $26 \cdot 0$ & $62 \cdot 6$ & $10 \cdot 8$ & $37 \cdot 3$ & $6 \cdot 7$ \\
\hline \multicolumn{10}{|c|}{ Monthly income (US\$) } \\
\hline $20-100$ & $59 \cdot 7151$ & $17 \cdot 4^{*}$ & 1.9 & $113 \cdot 8^{\star}$ & 2.9 & $61 \cdot 4^{*}$ & $11 \cdot 1$ & $36 \cdot 6$ & $6 \cdot 7$ \\
\hline$>100$ & $40 \cdot 3102$ & $18 \cdot 6^{\star}$ & 2.5 & $124 \cdot 7^{\star}$ & $21 \cdot 1$ & $65 \cdot 2^{*}$ & $12 \cdot 4$ & $38 \cdot 2$ & $7 \cdot 0$ \\
\hline \multicolumn{10}{|l|}{ Age (years) } \\
\hline $18-29$ & 63.6161 & $18 \cdot 1$ & 2.4 & $120 \cdot 0$ & $25 \cdot 2$ & $64 \cdot 0$ & 11.6 & $37 \cdot 7$ & $6 \cdot 4$ \\
\hline $30-45$ & 36.492 & 17.5 & $2 \cdot 0$ & 114.9 & $27 \cdot 9$ & $61 \cdot 0$ & 11.9 & $36 \cdot 5$ & $7 \cdot 6$ \\
\hline \multicolumn{10}{|l|}{ Marital status } \\
\hline Married & $59 \cdot 7151$ & $17 \cdot 7$ & $2 \cdot 2$ & $116 \cdot 1$ & $26 \cdot 6$ & $62 \cdot 8$ & 13.3 & $36 \cdot 7$ & $7 \cdot 2$ \\
\hline Unmarried & $40 \cdot 3102$ & $18 \cdot 1$ & 2.4 & $121 \cdot 2$ & $25 \cdot 7$ & 63.0 & $9 \cdot 1$ & 38.0 & $6 \cdot 3$ \\
\hline \multicolumn{10}{|c|}{ Non-addicted controls $(n 100)$} \\
\hline \multicolumn{10}{|c|}{ Education (years) } \\
\hline $0-10$ & 56.056 & $21 \cdot 3$ & 2.9 & $144 \cdot 1^{*}$ & $12 \cdot 4$ & 74.5 & 9.1 & 41.5 & $6 \cdot 3$ \\
\hline$>10$ & 44.044 & $20 \cdot 8$ & $2 \cdot 6$ & $136 \cdot 6^{*}$ & $18 \cdot 2$ & $72 \cdot 7$ & 8.3 & 44.0 & 7.5 \\
\hline \multicolumn{10}{|l|}{ Occupation } \\
\hline Business & 43.043 & $21 \cdot 6$ & $3 \cdot 0$ & $143 \cdot 7^{\star}$ & $14 \cdot 3$ & $77 \cdot 0^{*}$ & $6 \cdot 4$ & $40 \cdot 8^{*}$ & $6 \cdot 6$ \\
\hline Others & 57.057 & $20 \cdot 8$ & $2 \cdot 6$ & $137 \cdot 1^{*}$ & $16 \cdot 5$ & $71 \cdot 2^{\star}$ & $9 \cdot 6$ & $43 \cdot 9^{\star}$ & $6 \cdot 9$ \\
\hline \multicolumn{10}{|c|}{ Monthly income (US\$) } \\
\hline $20-100$ & 62.062 & $20 \cdot 8$ & 2.5 & 139.8 & 14.4 & 73.6 & 8.9 & 43.4 & $7 \cdot 6$ \\
\hline$>100$ & 38.038 & 21.6 & $3 \cdot 1$ & $140 \cdot 5$ & $18 \cdot 2$ & 73.9 & 8.7 & $41 \cdot 1$ & $5 \cdot 6$ \\
\hline \multicolumn{10}{|l|}{ Age (years) } \\
\hline $18-29$ & 59.059 & $20 \cdot 6^{\star}$ & 2.4 & $137 \cdot 8$ & $17 \cdot 4$ & $74 \cdot 7$ & $8 \cdot 1$ & $43 \cdot 9^{*}$ & $7 \cdot 4$ \\
\hline $30-45$ & 41.041 & $21 \cdot 8^{*}$ & $3 \cdot 1$ & $143 \cdot 1$ & $12 \cdot 8$ & $76 \cdot 7$ & 8.8 & $42 \cdot 6^{\star}$ & $6 \cdot 9$ \\
\hline \multicolumn{10}{|l|}{ Marital status } \\
\hline Married & 55.055 & $21 \cdot 7^{\star}$ & 2.9 & $141 \cdot 7$ & $14 \cdot 1$ & $72 \cdot 7$ & 9.2 & $42 \cdot 0$ & $6 \cdot 6$ \\
\hline Unmarried & 45.045 & $20 \cdot 4^{\star}$ & 2.4 & $137 \cdot 7$ & $17 \cdot 8$ & 74.9 & $8 \cdot 2$ & 43.2 & $7 \cdot 3$ \\
\hline
\end{tabular}

* Mean values within a column for a socioeconomic factor were significantly different by one-way ANOVA $(P<0.05)$. †For details of subjects and procedures see Table 1 and p. 508.

Table 6. Regression coefficient, standard error and $P$ values for multiple regression analysis

\begin{tabular}{|c|c|c|c|}
\hline Parameter* & $r$ & SE & $P$ value \\
\hline \multicolumn{4}{|l|}{ BMI } \\
\hline Income & 0.985 & 0.263 & 0.000 \\
\hline Education & 0.590 & 0.262 & 0.025 \\
\hline Group† & $-3 \cdot 215$ & 0.278 & 0.000 \\
\hline \multicolumn{4}{|l|}{$\begin{array}{r}\text { Haemoglobin } \\
\left(R^{2} 0 \cdot 170\right)\end{array}$} \\
\hline Income & 0.813 & 0.256 & 0.002 \\
\hline Group† & $-2 \cdot 196$ & 0.278 & 0.000 \\
\hline \multicolumn{4}{|l|}{$\begin{array}{c}\text { Total protein } \\
\left(R^{2} 0 \cdot 18\right)\end{array}$} \\
\hline Age & -2.472 & 0.009 & 0.008 \\
\hline Group† & -1.081 & $0 \cdot 129$ & 0.000 \\
\hline \multicolumn{4}{|l|}{$\begin{array}{l}\text { Albumin } \\
\qquad\left(R^{2} 0 \cdot 138\right)\end{array}$} \\
\hline Education & 0.252 & 0.073 & 0.001 \\
\hline Group† & -0.519 & 0.080 & 0.000 \\
\hline
\end{tabular}

${ }^{*} \mathrm{BMI}$, haemoglobin, total protein and albumin were taken as dependent variables. The independent variables (education, income and age) that were significantly correlated with the dependent variables are mentioned only. † Group indicated: group 1, non-addicted controls; group 2, drug addicts.
\& SanGiovanni, 1997; Solis-Pereyra et al. 1997). The malnourished drug addicts with sexually transmitted diseases may also, vulnerably, be at increased risk of HIV infection (Smith et al. 2000).

Results of one-way ANOVA showed that there was a positive correlation between education, income and nutritional indices of drug addicts, the outcome of which is well documented. But their habit of consuming poorquality nutrient-deficient foods (Himmelgreen et al. 1998) and neuropsychological deficits or brain dysfunction (Beatty \& Borrell, 2000) are conflicting with this finding. For their controls, however, although the trend and spectrum of this association was found to be different, apart from the negative influence of education on haemoglobin, the pattern of correlation is well predicted.

Multiple linear regression analysis showed that, in addition to illicit drug use, socioeconomic factors (education, income, age) significantly affected BMI and biochemical indices ranging from 13.8 to $31.2 \%$. After controlling these factors, group (non-drug addicts or drug-addicts) had a significant negative effect on the nutritional indices, even after controlling other socioeconomic 
variables in favour of controls. This finding is in agreement with the well-documented fact that socioeconomic factors have a contributory role to the nutritional status of an individual.

The cohort controls in the present study were recruited by convenience so that their age, height and socioeconomic factors were matched in group percentage to those of the drug addicts. Non-parametric analysis showed that the differences among these factors of the group were found to be insignificant (results not shown). This is because socioeconomic factors were matched by group percentage, and not by person to person. In the recruitment of cohort controls, it should be mentioned that although it would have been ideal to recruit a larger control group, because of financial constraint and ethical limitation in handling a large number of healthy human subjects, this was not feasible. However, there are a number of publications on casecontrol studies (Allard et al. 1998; Marangon et al. 1998; Islam et al. 2001), where there were less than half the number of cohort controls as case subjects. In our study, the drug addicts:non-addicted controls ratio used is consistent with that of the International Development Research Centre and World Health Organization (1991) recommended limit.

The present study reveals that drug addicts have poor nutritional status. Multiple malnutrition or nutrient deficiency is prevalent among them. Drug habit and sexually transmitted diseases have negative influence on their nutritional status. In addition to illicit drug use, some of the socioeconomic factors contribute to affect their nutritional indices. Since malnutrition or nutritional deficiency is the main cause of immunodeficiency (Chandra, 1997, 2001) that may influence susceptibility to HIV infection (Baum et al. 1995, 2000; Allard et al. 1998; Kotler, 1998), an efficient careful nutritional intervention would be of particular importance in the clinical management of drug addicts, as well as of HIV-infected or AIDS patients.

\section{Acknowledgements}

The authors thank the Ministry of Science and Technology, the Government of Bangladesh for their financial support and are also grateful to the Director, Central Drug Addiction Treatment Hospital, Dhaka, Bangladesh for his kind assistance.

\section{References}

Allard JP, Aghdassi E, Chau J, Salit I \& Walmsley S (1998) Oxidative stress and plasma antioxidant micronutrients in humans with HIV infection. American Journal of Clinical Nutrition 67, 143-147.

Baum MK, Shor-Posner G \& Campa A (2000) Zinc status in human immunodeficiency virus infection. Journal of Nutrition 130, 1421S-1423S.

Baum MK, Shor-Posner G, Lu Y, Rosner B, Sauberlich HE, Fletcher MA, Szapocznik J, Eisdorfer C, Buring JE \& Hennekens CH (1995) Micronutrients and HIV-1 disease progression. AIDS 9, 1051-1056.

Beatty WW \& Borrell GK (2000) Forms of knowledge, cognitive impairment and drug abuse: a demonstration. Progress in Neuro-psychopharmacology and Biological Psychiatry 24, 17-22.

Beisel WR (1996) Nutrition in paediatric HIV infection: setting the research agenda Nutrition and immune function: Overview. Journal of Nutrition 126, Suppl., 2611S-2615S.

Bluthenthal R, Kral A, Gee L, Erringer E \& Edlin E (2000) The effect of syringe exchange use on high risk IDUs: a cohort study. AIDS 14, 605-611.

Booth R, Kwiatkowski C \& Chitwood D (2000) Sex-related HIV risk behaviors: differential risk among IDUs, crack smokers, and IDUs who smoke crack. Drug and Alcohol Dependence 58, 219-226.

Brown SM, Stimmel BT \& Taub RN (1974) Immunologic dysfunction in heroin addicts. Archives of Internal Medicine 134, $1001-1006$.

Califano JA Jr (1998) Substance abuse and addiction - the need to know. American Journal of Public Health 88, 9-11.

Carr DJJ \& Serou M (1995) Exogenous and endogenous opioids as biological response modifiers. Immunopharmacology 31, $59-71$.

Chandra RK (1997) Nutrition and the immune system: an introduction. American Journal of Clinical Nutrition 66, 460S-463S.

Chandra RK (2001) Introduction and state of the art and science of nutrition and immunology (abstract). In The 17th International Congress of Nutrition, 27-31 August 2001, Vienna, Austria, p. 288 [I Elmadfa and J Konig, editors]. New York and London: Medical and Science Publishers.

Chlebowski RT, Beall G \& Grosvenor M (1993) Long term effects of early nutritional support with new enterotropic peptide-based formula vs standard enteral formula in HIVinfected patients: randomized prospective trial. Nutrition 9, 507-512.

Choi KH, Xiwen Z, Shuquan Q, Yiee K \& Mandel J (2000) HIV risk among patients attending sexually transmitted diseases clinic in China. AIDS and Behavior 4, 111-119.

Courssons-Reed ME, Dykstra LA \& Lystle DT (1994) Pavlovian conditioning of morphine induced alterations of immune status. Brain Behavior Immunology 8, 204-217.

Finnegan LP (1998) Perinatal Morbidity and Mortality in Substance Using Families: Effects and Intervention Strategies, pp. 1-21. Rockville, MD: NIDA, NIH, US Department of Health and Human Services.

Food and Agriculture Organization (1994) BMI as an indicator of CED. In Body Mass Index: A Measure of Chronic Energy Deficiency in Adults, pp. 17-20 [PS Shetty and WPT James, editors]. Rome: FAO.

Food and Agriculture Organization (1995) State of Nutrition in Bangladesh, pp. 1-66. Dhaka, Bangladesh: FAO.

Ganong WF (1997) Review of Medical Physiology, 18th ed. pp. 481-508. New Jersey, USA: Prentice-Hall International, Inc.

Hegde HR, Woodman RC \& Sankarn K (1999) Nutrients as modulators of energy in AIDS. Journal of the Association of Physicians of India 47, 318-325.

Himmelgreen DA, Perez-Escamilla R, Segura-Millan S, Romero-Daza N, Tansescu M \& Sin M (1998) A comparison of the nutritional status and food security of drug-using and non-drug-using Hispanic women in Hartford, Connecticut. American Journal of Physical Anthropology 107, 351-361.

International Development Research Centre and World Health Organization (1991) Designing and Conducting Health System Research Projects, vol. 2, part 1, pp. 195-218 [CM Varkevisser, I Pathmanathan and A Brooconlee, editors]. Geneva: WHO.

Islam SN, Hossain KJ \& Ahsan M (2000) Sexual life style, drug 
habit and sociodemographic status of the drug addicts in Bangladesh. Public Health 114, 389-392.

Islam SN, Hossain KJ \& Ahsan M (2001) Original communication: Serum vitamin E, C and A status of the drug addicts undergoing detoxification: influence of drug habit, sexual practice and life style factors. European Journal of Clinical Nutrition 55, 1022-1027.

Johnson A \& Gerstein DR (1998) Initiation of use of alcohol, cocaine, and other substances in US birth cohorts since 1919 American Journal of Public Health 88, 27-33.

Kotler DP (1998) Antioxidant therapy and HIV infection. American Journal of Clinical Nutrition 67, 7-9.

Latham MC (1997) Human Nutrition in the Developing World FAO, Food and Nutrition Series no 29, pp. 147-156. Rome: FAO.

Leklem JE (1996) Vitamin $\mathrm{B}_{6}$. In Present Knowledge in Nutrition, 7th ed. pp. 174-183 [EE Ziegler and LJ Filer Jr, editors]. Washington, DC: ILSI Press.

Levine M, Rumsey S \& Wang Y (1996) Vitamin C. In Present Knowledge in Nutrition, 7th ed. pp. 146-159 [EE Ziegler and LJ Filer Jr, editors]. Washington, DC: ILSI Press.

Marangon K, Herbeth B, Lecomte E, Paul-Dauohin A, Grolier P, Chancerelle Y, Artur Y \& Siest G (1998) Diet, antioxidant status, and smoking habits in French men. American Journal of Clinical Nutrition 67, 231-239.

Mason S \& Swash M (1980) The mouth and throat. In Hutchison's Clinical Method, 17th ed. pp. 62-70 [S Mason and M Swash, editors]. London: ELBS, A Baillieze Tindall Publications.

Miyagi AU, Chuang T, Lam KM, Kung HF, Wang JM, Osburn BI \& Chuang RY (2000) Opioids suppress chemokine-mediated migration of monkey neutrophils and monocytes - an instant response. Immunopharmacology 47, 53-62.

Mohs ME, Watson RR \& Leonard-Green T (1990) Nutritional effects of marijuana, heroin, cocaine and nicotine. Journal of the American Dietetic Association 90, 1261-1267.

Morabia A, Fabre J, Chee E, Zeger S, Orsat E \& Robert A (1989) Diet and opiate addiction: a quantitative assessment of the diet of non-institutionalized opiate addicts. British Journal of Addicts 84, 173-180.

Nagati K (2001) Multiple approaches to micronutrient deficiency in developing countries (abstract). In The 17th International Congress of Nutrition, 27-31 August 2001, Vienna, Austria, p. 7 [I Elmadfa and J Konig, editors]. New York and London: Medical and Science Publishers.

Ogilvie C \& Evans CC (1987) External manifestation of disease.
In Chamberlain's Symptoms and Signs in Clinical Medicine, 11th ed. pp. 36-70 [C Ogilvie and CC Evans, editors]. Bristol: ELBS, IOP Publishing Ltd.

Rand ML \& Murray RK (2000) Plasma proteins, immunoglobulins, and blood coagulation. In Harpar's Biochemistry, 25th ed. pp. 737-762 [RK Murray, DK Granner, PA Mayes and VW Rodwell, editors]. Stamford, CT: Appleton and Lange.

Rouveix B (1992) Opiates and immune function: consequence on infectious disease with special reference to AIDS. Therapie 47, 503-512.

Scrimshaw NS \& SanGiovanni JP (1997) Synergism of nutrition, infection, and immunity: an overview. American Journal of Clinical Nutrition 66, 464S-477S.

Shearman DJC (1996) Disease of the alimentary tract and pancreas. In Davidson's Principle and Practice of Medicine, 17th ed. pp. 405-482 [CRW Edwards, D Bouchier, C Haslett and E Chilverse, editors]. Edinburgh: ELBS, Churchill Livingstone.

Smith DK, Gwinn M, Selik RM, Miller KS, Dean-Gaitor HD, Ma'at PI, DeCock KM \& Gayle HD (2000) HIV/AIDS among African Americans: progress or progression? AIDS 14, $1237-1248$.

Solis-Pereyra B, Aattouri N \& Lemonnier D (1997) Role of food in the stimulation of cytokine production. American Journal of Clinical Nutrition 66, 521S-525S.

Thomas PT, Bhargana HN \& House RV (1995) Immunomodulatory effects of in vitro exposure to morphine and its metabolites. Pharmacology 50, 51-62.

United Nations International Drug Control Programme (1997) Recent trends and development in cultivation, production, trafficking and consumption: an overview. In World Drug Report, pp. 16-43. New York: UNDCP, Oxford University Press.

Varela P, Marcos A, Ripoll S, Santacruz I \& Requejo AM (1997a) Effects of human immunodeficiency virus infection and detoxification time on anthropometric measurements and dietary intake of male drug addicts. American Journal of Clinical Nutrition 66, 509S-514S.

Varela P, Marcos A, Santacruz I, Ripoll S \& Requejo AM (1997b) Human immunodeficiency virus infection and nutritional status in female drug addicts undergoing detoxification: anthropometric and immunologic assessments. American Journal of Clinical Nutrition 66, 504S-508S.

Vasko ME (1992) Drug abuse and dependence. In Goth's Medical Pharmacology, 13th ed. pp. 336-353 [WO Clerk, DE Brater and AR Johnson, editors]. St. Louis, USA: Mosby Year Book. 